\title{
Third stage
}

Sheila Hollins

Cornelius Katona

Femi Oyebode

Richard Williams

Tony Zigmond

(non-transferable)

1172

924

1072

\section{Fourth stage}

\section{Sheila Hollins}

Cornelius Katona

Femi Oyebode

Richard Williams

Tony Zigmond

(non transferable)

Professor Sheila Hollins was therefore elected to take office from 21 June 2005.

\section{Race equality in the College: what have we achieved?}

The College has been involved in race equality work since the early 1980 s, but has anything really changed over the last quarter of a century? We believe that it has but, regrettably, only in recent years.

In 1987, under the wise chairmanship of the late Professor Kenneth Rawnsley, a Council Report was produced entitled Psychiatric Practice and Training in British Multi-ethnic Society (CR10). This thoughtful report was an attempt by the College to increase awareness of racial discrimination and prejudice and to take steps to minimise their effects. It had the following terms of reference:

- to explore issues attending the training of psychiatrists and the practice of psychiatry in British multi-ethnic society;

- to investigate the problems of discrimination against trainees, other doctors in psychiatry and patients on the grounds of race and to make recommendations.

Some changes were introduced in the College as a result of this report. Ethnic monitoring of the membership began as early as 1990, although very little use was made of the data collected. Equal opportunities was included in the training day for College assessors on advisory committees.

A further Council Report was produced in 1996 entitled Report of the Working Party to Review Psychiatric Practice and Training in a Multi-Ethnic Society (CR48). This was chaired by the Dean, Professor John Cox, and was a review of the recommendations of the Rawnsley report.

It was, however, the third Council Report, Report of the Ethnic Issues Project Group (CR92) which was the real catalyst for change. It was approved by Council in February 2001 and was influenced by a series of meetings with Black and minority ethnic (BME) user group representatives. From the outset it was intended to be action-orientated. It contained the following ten recommendations that had been identified as College priorities:

- external systematic review of College structures

- scrutiny of appointment procedures

- zero tolerance of racially discriminatory behaviour

- dialogue with BME user groups

- all psychiatrists to receive training to be culturally sensitive

- meet training expectations of psychiatrists on the Overseas Doctors' Training Scheme

- awareness of potential for discrimination in mental health legislation

- encourage members to ensure that BME communities have equal access to services

- ensure that epidemiological studies include BME groups in community studies

- establish a special committee on ethnic issues.

These recommendations cover not just the activities of the College as an institution, but also clinical practice and the provision of mental health services for BME communities.

Early in 2001 three significant events occurred close to each other. The first was the implementation of a key recommendation in this latest report - namely that the College should undertake an external systematic review of its structures. The decision was made to appoint Professor Kamlesh Patel and his team from the Centre for Ethnicity and Health at the University of Central Lancashire. The second was the publication of the Race Relations (Amendment) Act which came into force on 2 April 2001. This listed the College as a public authority with a 'general duty'. The third was the establishment of a special committee on ethnic issues. The positions of chair and committee members were advertised in the Psychiatric Bulletin. Dr Parimala Moodley was appointed chair and a small committee was appointed, mainly consisting of members who had not previously been involved in College activities. Three trainees were appointed to the committee.

These three events were significant because together they have helped to ensure that the recommendations contained in CR92 are implemented and that this time real changes will occur in the College. Already some real progress has been made.

As stated above, the College was named in the Race Relations (Amendment) Act as a public authority organisation with a general duty. The general duty requires specified organisations to:

- eliminate unlawful racial discrimination

- promote equality of opportunity

- promote good relations between persons of different racial groups.

Although the College was not listed in the Act as an organisation with 'specific duties' (and thus obliged to produce a race equality scheme), it was agreed by Council that it would be good practice in meeting the general duty to produce such a scheme.

The College used the ten recommendations from CR92 as the basis for its Race Equality Statement of Intent. This states in the introduction that the Royal College of Psychiatrists is committed to:

- race equality in the promotion and practice of psychiatry by the eradication of unlawful discrimination;

- the promotion of equal opportunities and the promotion of good race relations with respect to its role as an employer, in the development and implementation of the standards and practice for psychiatrists and in the development and implementation of Council policies and procedures.

The Race Equality Statement of Intent was the basis for the College's Race Equality Scheme, which described what the College would do to meet the general and specific duties under the Race Relations (Amendment) Act 2000. Council approved this in June 2002.

The Race Equality Action Plan describes how the scheme will be implemented. This is a practical work plan that outlines in detail the work that the College will need to perform in order to realise its Statement of Intent. It identifies the individuals responsible for leading the specific areas and gives a timetable. Most areas of College activity are included in this plan. The plan was approved by Council in April 2003.

So what has the College achieved to date and what remains to be done? Some substantial progress has been made, some of which may be more visible to the College members, i.e. ethnic monitoring. The following is a summary of progress to date.

\section{Ethnic monitoring}

The College has achieved one of the highest return rates for any organisation. Approximately $90 \%$ of College members have now responded to the form with the new Office for National Statistics ethnic categories. As a result we now know that the percentage of BME members increased from $13 \%$ in 1994 to $24 \%$ in 2004. We have chosen ethnic monitoring as the initial tool by which to examine all 
aspects of College life. By doing this, we shall determine the levels of discrimination operating within the College.

\section{Analysis of returns}

Council agreed that data should be collected on the establishment and membership of committees, election results, election to Fellowship and Honorary Fellowship, Clinical Excellence Awards, examinations pass rates and many other areas of College activity. These data have been collected for 2003 and 2004. The comparative data will be presented to Council, the Court of Electors and the various committees. Committees will be asked to comment on the data and to make recommendations on how to address any imbalances. Key data collected in 2004 will be uploaded on the College website together with the 2003 data (http://www.rcpsych.ac.uk/ college/equality_diversity.htm)

\section{Guidance to authors of College policy}

A template has been produced which is based on the Commission for Racial Equality statutory code. It gives guidance to chairs of current and future College policy working groups. The Special Committee on Ethnic Issues currently reviews each Council report before publication to ensure that this guidance is met. The template asks two questions, namely:

- Does the policy, standard or procedure affect some racial groups differently?

- Is there any public concern that the function or policy in question is causing discrimination?

\section{Revision of bye-laws}

Professor Kamlesh Patel and his team have checked the College bye-laws and regulations to ensure that they are free of discrimination. If approved by Council, amendments concerning the nomination of fellows will be submitted to the AGM and Privy Council. It is proposed that in future nominations may be supported by members, rather than restricting this to fellows. Similar amendments concerning eligibility for College office are also proposed. Increasing use will also be made of open appointments procedures.

\section{Good Psychiatric Practice (2nd edn)}

Good Psychiatric Practice sets standards for psychiatrists and is one of the College's most important publications. The commitment to being fully sensitive to gender, ethnicity and culture and the commitment to equality, anti-discriminatory practice and working with diversity are now considered core attributes for psychiatrists.

\section{Inclusion of cultural capability questions in MRCPsych}

Members of the Special Committee on Ethnic Issues and the Transcultural Psychiatry Special Interest Group have forwarded written questions to the chief examiner for inclusion in the MRCPsych examination. The Ethnic Issues Committee has also suggested that other parts of the MRCPsych examination, such as objective structured clinical examinations and clinical examination, include issues of cultura capability.

\section{Development of BME carer and user network}

Some progress has been made in developing networks with BME user and carer groups. The College has sponsored two conferences set up to develop such a network and participates in the e-mail discussion group established following these conferences. We shall explore the development of regional networks with NIMHE (National Institute for Mental Health in England) as we establish College divisional offices throughout the UK and Ireland.

\section{Harassment and bullying policy}

The College is committed to zero toler ance regarding racial harassment and bullying by or between members, associates, trainees and staff. A policy developed by the Ethnic Issues Committee was endorsed by Council in January 2005. The College is proposing to establish a confidential help and advice service for members who may be experiencing difficulties in relation to work-related stress, bullying, racial and other discrimination.

\section{Training manual for cultural capability}

A training manual for use both in the MRCPsych education programme and for continuing professional development is being prepared by Professor Richard Williams and Dr Parimala Moodley.

\section{Consultation with} members regarding the Race Equality Action Plan

The Centre for Ethnicity and Health devised a questionnaire which was sent to all members and associates in the UK and Ireland in January 2005. The Strategy and Action Plan will be reviewed in the light of comments received. It is a requirement of the Race Relations (Amendment) Act to consult with members on the Race Equality Strategy and Action Plan.

\section{Focus groups}

The Centre for Ethnicity and Health is convening a series of focus groups and organising interviews with members, associates and overseas doctors on the sponsored training scheme to seek feedback on their experiences. Doctors interested in participating should contact the team at jbashford@uclan.ac.uk.

\section{Survey to identify members who can act in advisory capacity regarding BME resources}

The College will shortly be sending out a questionnaire to members asking them if they would be prepared to act in an advisory capacity regarding BME resources. A database will then be prepared and maintained by the College.

\section{Ensure that research takes appropriate account of race and culture}

The College, through its College Research Unit, Research and University Psychiatry Committee, will develop a research strategy relating to the inclusion of BME communities in research.

\section{Promotion of good practice in use of mental health legislation}

The College will promote good practice among psychiatrists and other professional groups in the use of mental health legislation regarding BME patients through the development of guidance notes and setting standards. The Mental Health Bill has the potential to increase discrimination and the College has been vocal in expressing this concern.

It is clear from the above that the College has made real progress in addressing race equality issues over the past 3 years. However we cannot afford to be complacent. There is much more to do. We have developed a communications strategy to ensure that the membership and the wider community is informed of work in this area.

Further work needs to be carried out in developing dialogues with BME users and 
carers, many of whom are outraged at the quality of the services they have received. The College also needs to do much more to address the difficulties faced by its affiliates or non-consultant career grade doctors, some of whom have been at the receiving end of an invidious subtle form of indirect discrimination for most of their careers.

The BMA published a report in 2003 entitled Racism in the Medical Profession: The Experience of UK Graduates. This report looks at the experience and beliefs of one cohort of doctors in relation to racism. It shows that racism is widespread in the NHS and is experienced by doctors from minority ethnic groups that are UKtrained as well as those from overseas. It makes sober reading.

So, despite appearances to the contrary, the College, until recently, got off to a slow start in grappling with race equality issues, both within the College and in the wider community. This time round there must be a difference.

Council has approved an action plan that in due course will affect every area of College activity. The College, at the highest level, is committed to seeing real change. With the help of College members the Royal College of Psychiatrists can become a fine example of an institution which has honestly confronted its institutional racism and is beginning a journey which it hopes will end in the eradication of discrimination from its structures. This should lead to a real improvement in the care and treatment of some of our most vulnerable users - which is our real goal. We have started a far-reaching programme. A momentum has now built up which must not slow down.

Parimala Moodley Chair of Ethnic Issues Committee, Vanessa Cameron Chief Executive

\section{Proposal for a special interest group in approaches to conflict, trauma and disasters}

Procedure for establishing a special interest group:

(1) Any member wishing to establish a special interest group shall write to the Registrar with relevant details.

(2) The Registrar shall forward the application to Council.

(3) If Council approves the principle of establishing such a special interest group, then it will direct the Registrar to place a notice in the Bulletin, or its equivalent, asking members of the College to write in support of such a group and expressing willingness to participate in its activities.

(4) If at least 120 members reply to this notice within 4 months of publication, then Council shall formally approve the establishment of the special interest group.

In accordance with this procedure Council has approved a proposal for the establishment of a special interest group in approaches to conflict, trauma and disasters.

\section{Background to the proposal from \\ Dr Nathaniel Minton:}

The proposal for the group was initially suggested to me by Professor Driss Moussaoui, Casablanca, Chair of the World Psychiatric Association (WPA) Ethical Committee, whom I first met at the International Congress of the World Association for Social Psychiatry (WASP) in Agra in 2001. I had been asked by the President of WASP, Professor S. Sharma, to organise a session on conflict resolution there on the strength of my paper on that subject (please see my updated paper; Journal of the World Association for Dynamic Psychiatry, January 2004, 204/ 205, 89-98). Since then I have organised two successful conferences on conflict resolution, one in Malta in 2003 and the first in Cobham, Surrey, in May 2002. I am currently organising a third conference with the Andrew Sims Centre at the Institute of Psychiatry in July 2005. This is being co-sponsored by the WPA and the World Health Organization and is supported by the College.

A College special interest group on approaches to conflict, trauma and disaster would be best served by a combination of the perspectives of social psychiatry and psychotherapy. In previous conferences, experts from opposing sides of international conflict have come together in friendly dialogue; this will hopefully be repeated in July 2005 at the London conference, a highlight of which will be a symposium on The Contribution of Psychotherapy to Peace, with reference to the Israeli/Palestinian conflict and with eminent speakers from the two sides. Professor Hamid Ghodse, Chair of the College Board of International Affairs, will also chair a plenary session at the conference. Dr George Ikkos, Chair of the College London Division, is on the conference organising committee and will be an active participant.

The aim of the special interest group would be to try to promote the discussion and development of approaches to conflict, trauma and disasters, through the auspices of the College. I would be happy to act as a group facilitator, as I have developed an interest in the field of conflict resolution over the last 4 years and an appreciation of the difficulties and opportunities that it affords. If established the special interest group could lobby international bodies, and work with charities and welfare economists in the field.

The idea of a special interest group on conflict resolution is strongly supported by Professors Roy McClelland, Belfast, and John Cox, who is now the Secretary General of WPA. Both professors were key contributors to the Cobham and Malta conferences. The President of WPA, Professor Ahmed Okasha, Cairo, who wholeheartedly supports the next conference, is particularly interested in conflict resolution, and at the Malta meeting he set up a WPA task force because of the WPA's grave concern over the escalating violence in the Middle East.

Members are invited to write in support of this group and express willingness to participate in its activities. Interested members should write to the Registrar care of Miss Sue Duncan at the College. If 120 members reply to this notice within 4 months of publication, then Council shall formally approve the establishment of this special interest group.

Dr Andrew Fairbairn Registrar, Royal College of Psychiatrists

\section{Proposal for a special interest group in occupational psychiatry}

Procedure for establishing a special interest group:

(1) Any member wishing to establish a special interest group shall write to the Registrar with relevant details

(2) The Registrar shall forward the application to Council.

(3) If Council approves the principle of establishing such a special interest group, then it will direct the Registrar to place a notice in the Bulletin, or its equivalent, asking members of the College to write in support of such a group and expressing willingness to participate in its activities.

(4) If at least 120 members reply to this notice within 4 months of publication, then Council shall formally approve the establishment of the special interest group.

In accordance with this procedure, Council has approved a proposal for the establishment of a special interest group in occupational psychiatry.

\section{Background to the proposal from Dr John Sharkey:}

\section{The importance of work}

When we think of who and what we are, work is an important consideration. 